\title{
Flow Cytometry Analysis of Peripheral Blood B Cell Distribution of Patients with Multiple Sclerosis
}

\author{
Multipl Skleroz Hastalarında Periferik Kan B Lenfosit Alt Gruplarının Akım Sitometrisi
} ile Değerlendirilmesi

\author{
Vuslat Yılmaz¹, Deniz Ak Tura², Canan Ulusoy¹, Duygu Özkan Yaşargün², Suzan Adın Çınar ${ }^{3}$, Recai Türkoğlu² \\ ${ }^{1}$ Istanbul University Aziz Sancar Institute of Experimental Medicine, Department of Neuroscience, Istanbul, Turkey \\ 2Haydarpasa Numune Training and Research Hospital, Clinic of Neurology, Istanbul, Turkey \\ 3/stanbul University Aziz Sancar Institute of Experimental Medicine, Department of Immunology, Istanbul, Turkey
}

\begin{abstract}
Objective: Multiple sclerosis (MS) is a central nervous system (CNS) disease characterized by autoimmune inflammation and neurodegeneration. Damage to the CNS is thought to be mediated predominantly by activated pro-inflammatory T cells and antibody secreting B cells. Strong evidence of B cell functions in MS pathogenesis has come from trials of B cell- depleting treatment. In this study, the peripheral blood frequencies of B cell subsets were measured using flow cytometry in patients to determine the disease-specific B cell differences that might be associated with the evolution to progressive forms of MS.
\end{abstract}

Materials and Methods: Peripheral blood mononuclear cells were separated from patients and healthy controls [relapsing-remitting MS (RRMS) and secondary progressive MS (SPMS)]. Cells were stained with anti-human monoclonal antibodies (CD19-APC, CD27-FITC, IgD-APC/Cy7, CD138-PE, CD24-PerCP and CD38-Alexa fluor 700), and analyzed using flow cytometry.

Results: There were no significant differences between the MS group and healthy controls by means of peripheral blood frequencies of B cells, immature, naïve, classic memory, plasma, plasmablasts, and regulatory B cells. Only higher naïve B cell frequency tendency was determined in patients with RRMS as compared with patients with SPMS and healthy controls.

Conclusion: Peripheral blood B cell subset measurements are not likely to be used as a biomarker for prediction of disease progression. Although B cells have a well-known pathogenic significance, B cell population alterations do not occur during the progression of the disease.

Keywords: Multiple sclerosis, B cell, peripheral blood

$\ddot{\mathbf{O z}}$

Amaç: Multipl skleroz (MS), bir merkezi sinir sistemi hastalı̆̆ıdır ve otoimmün inflamasyon ve nörodejenerasyon ile karakterizedir. Hastalıkta aktif olan enflamasyon ve proinflamatuar T hücresi dışında antikor yapan B hücrelerinin de rolü büyüktür. Periferik B hücrelerinin MS hastalığındaki rolü, B hücrelerinin deplesyonu ile elde edilen bulgulara dayanmaktadır. Çalışmamızda periferik kandaki B hücre alt tiplerinin akım sitometrisi ile belirlenmesi ve hastalık alt gruplarındaki olası farklarının belirlenmesi hedeflendi.

Gereç ve Yöntem: MS hasta grubu [relapsing-remitting MS (RRMS) ve sekonder progresif MS (SPMS)] ve sağliklı donörlerden periferik kan mononükleer hücreleri izole edildi. Bu hücreler, B hücresine spesifik monoklonal antikorlar ile (CD19-APC, CD27-FITC, IgD-APC/Cy7, CD138-PE, CD24-PerCP ve CD38Alexa fluor 700) işaretlendi ve akım sitometrisi ile değerlendirildi.

\footnotetext{
Address for Correspondence/Yazışma Adresi: Vuslat Yılmaz MD, Istanbul University Aziz Sancar Institute of Experimental Medicine, Department of Neuroscience, Istanbul, Turkey

Phone: +90 5337435573 E-mail: vuslaty@hotmail.com ORCID ID: orcid.org/0000-0002-4809-2966

Received/Geliş Tarihi: 01.08.2017 Accepted/Kabul Tarihi: 18.08.2017

${ }^{\circ}$ Copyright 2017 by Turkish Neurological Society

Turkish Journal of Neurology published by Galenos Publishing House.
} 
Bulgular: MS grubu ile sağlıklı donörler arasında B hücre, immatür, naif, klasik bellek, plazma, plazmablast ve düzenleyici B hücreleri dă̆ılımları faklı değildi. Yalnızca naif B hücre frekansı RRMS hastalarında SPMS grubu ile kıyaslandığında görece yüksekti.

Sonuç: Periferik kan B hücre alt tipleri, hastalık ve hastalık alt grupları arasında farklı olmaması sebebiyle biyo-belirteç olarak kullanılması düşünülemez. B hücrelerinin MS hastalığındaki patojenik önemi iyi bilinmekle beraber çalışmamız B hücresi popülasyon değişikliklerinin hastalığın progresyonu sırasında gerçekleşmediğini göstermektedir.

Anahtar Kelimeler: Multipl skleroz, B hücresi, periferik kan

\section{Introduction}

Multiple sclerosis (MS) is a severe disease of the central nervous system (CNS) characterized by autoimmune inflammation and neurodegeneration. Damage to the CNS is thought to be mediated predominantly by activated pro-inflammatory $\mathrm{T}$ cells and antibody- secreted B cells.

Strong evidence supporting B cell functions in MS pathogenesis has come from clinical trials of B cell-depleting treatment with rituximab in patients with relapsing-remitting MS (RRMS). In patients under rituximab treatment, the survival of antibodysecreting plasma cells and decrease in T cell numbers indicated the importance of other B cell functions in MS such as antigen presentation, co-stimulation, and cytokine production (1). B cells also have the ability to cross the blood brain barrier and undergo stimulation, antigen-driven affinity maturation and clonal expansion $(2,3,4)$.

Despite accumulating data on the role of $\mathrm{B}$ cells in progressive forms of MS, there is relatively less information on B cell actions in earlier stages of the disease. Activated B cells, memory B cells, regulatory $\mathrm{B}$ cells, and plasma cells have been found in peripheral blood and/or cerebrospinal fluid (CSF) of patients with RRMS and patients with clinically isolated syndrome (CIS) $(5,6,7,8,9)$. However, very little is known on the alteration of B cell subsets in the transitional stage of MS, when patients progress from RRMS to secondary progressive MS (SPMS).

In this study, the peripheral blood frequencies of B cell subsets were measured using flow cytometry in patients with RRMS and SPMS to determine the disease-specific B cell differences that might be associated with the evolution to progressive forms of MS.

\section{Materials and Methods}

\section{Study Groups}

Nineteen patients with MS who satisfied the revised McDonald Criteria (9) were included and 20 age/sex-matched healthy individuals were included as controls (Table 1). The MS group consisted of 8 patients with RRMS and 11 with SPMS. Individuals with other coexisting neurologic or systemic disorders were excluded. All patients with MS underwent cranial magnetic resonance imaging (MRI) with the same $1.5 \mathrm{~T}$ scanner at the time of enrollment. Oligoclonal bands (OCB) were investigated in all patients. The study protocol was approved by Haydarpasa Numune Training and Research Hospital's Local Ethics Committee (Protocol number: HNEAH-KAEK 2016/110) and all subjects gave informed consent. Patients were in remission during blood sampling and had not received steroid treatment within 30 days of the blood collection, but were using immunomodulating medications (11 interferon- $\beta, 5$ glatiramer acetate and 3 fingolimod).

Phenotypic Distribution of Peripheral B Cells Using Flow Cytometry

In order to obtain standard conditions, peripheral blood mononuclear cells (PBMCs) were separated through Ficoll density gradient centrifugation. Cells were resuspended in freezing solution and stored in liquid nitrogen. Frozen PBMCs were thawed and washed in complete medium (enriched with $10 \%$ fetal calf serum, $1 \%$ MEM Vitamin, $1 \%$ L-Glutamine, $1 \%$ Na-Pyruvate, $1 \%$ NonEssential amino acids, $1 \%$ Penicillin-Streptomycin). Cells were stained with anti-human monoclonal CD19-APC, CD27-FITC, IgD-APC/Cy7, CD138-PE, CD24-PerCP, and CD38-Alexa fluor 700 (Biolegend) conjugates for $30 \mathrm{~min}$ at $4{ }^{\circ} \mathrm{C}$, then washed with phosphate-buffered saline (PBS) and resuspended in PBS, and 6 color immunofluorescence staining was performed (BD FACS Aria II). At least $5 \times 10^{5}$ cells were acquired for each sample and data were analyzed using the FlowJo software (Figure 1).

\section{Statistical Analysis}

Demographic and clinical features of the participants were compared using the chi-square test, analysis of variance (ANOVA), Student's t-test, and Mann-Whitney U tests, as required. B cell subset frequencies were compared using ANOVA and Tukey's post-hoc test in multiple group comparisons and Student's t-test in two-group comparisons. $\mathrm{P}<0.05$ was considered statistically significant.

\begin{tabular}{|c|c|c|c|}
\hline & MS (n=19) & $\mathrm{HC}(\mathrm{n}=20)$ & $\mathrm{p}$ \\
\hline Sex (female/male) & $9 / 10$ & $12 / 8$ & $0.527^{*}$ \\
\hline Age (years) & $40.9 \pm 7.9$ & $31.5 \pm 6.1$ & $0.084^{* *}$ \\
\hline $\begin{array}{l}\text { Age at disease onset } \\
\text { (years) }\end{array}$ & $26.3 \pm 8.5$ & - & - \\
\hline Disease duration (years) & $14.6 \pm 4.7$ & - & - \\
\hline Number of relapses & $7.8 \pm 4.0$ & - & - \\
\hline $\begin{array}{l}\text { Number of patients with } \\
\text { CSF OCB }\end{array}$ & 11 & - & - \\
\hline EDSS score & $4.2 \pm 1.6$ & - & - \\
\hline \multicolumn{4}{|c|}{$\begin{array}{l}\text { MS: Multiple sclerosis, CSF: Cerebrospinal fluid, OCB: Oligoclonal bands, HC: } \\
\text { Healthy controls, EDSS: Expanded Disability Status Scale. } \\
\text { Numerical values were signified in the form of average } \pm \text { standard deviation. } \\
{ }^{*} \text { Chi-square, }{ }^{* *} \text { Student's t-test }\end{array}$} \\
\hline
\end{tabular}




\section{Results}

The demographic and clinical features of the patients with MS (RRMS and SPMS) and healthy controls (HC) are listed in Tables 1 and 2. Patients with SPMS showed trends towards exhibiting higher age, disease duration, number of relapses, and Expanded Disability Status Scale (EDSS) scores, as expected. Number of patients with OCBs was comparable among the RRMS and SPMS groups (Table 2 ).

There were no significant differences between the MS group and $\mathrm{HC}$ by means of peripheral blood frequencies of $\mathrm{CD}_{19}{ }^{+} \mathrm{B}$ cells $(\mathrm{p}=0.99), \mathrm{CD} 19^{+} \mathrm{IgD}^{-} \mathrm{CD} 27^{-}$immature $(\mathrm{p}=0.3), \quad \mathrm{CD} 19^{+} \mathrm{IgD}^{+} \mathrm{CD} 27^{-}$naïve $(\mathrm{p}=0.3), \quad \mathrm{CD} 19^{+} \mathrm{IgD}^{-}$ $\mathrm{CD} 27^{+}$classic memory $(\mathrm{p}=0.9), \mathrm{CD} 19^{+} \mathrm{CD} 38^{+} \mathrm{CD} 138^{+}$plasma $(\mathrm{p}=0.7), \quad \mathrm{CD} 19^{+} \mathrm{CD} 38^{++} \mathrm{CD} 138^{-}$plasmablasts $(\mathrm{p}=0.3)$, and $\mathrm{CD} 19^{+} \mathrm{CD} 24^{++} \mathrm{CD} 38^{++}$regulatory $\mathrm{B}$ cells $(\mathrm{p}=0.08)$ as assessed using Student's t-test (Figure 2).

Also, the distribution of $\mathrm{B}$ cell subsets among patients with RRMS, SPMS, and the HC was found to be comparable and statistically insignificant using ANOVA and Tukey's posthoc test. Only higher naïve B cell frequency tendency was determined in patients with RRMS as compared with those with SPMS and the HC. However, this difference did not attain statistical significance $(\mathrm{p}=0.128)$. Frequencies of immature $(\mathrm{p}=0.529)$, classic memory $(\mathrm{p}=0.175)$, plasma $(\mathrm{p}=0.707)$, plasmablast $(\mathrm{p}=0.337)$, and Breg cells $(\mathrm{p}=0.312)$ were not different in the RRMS, SPMS or HC groups (Figure 3).

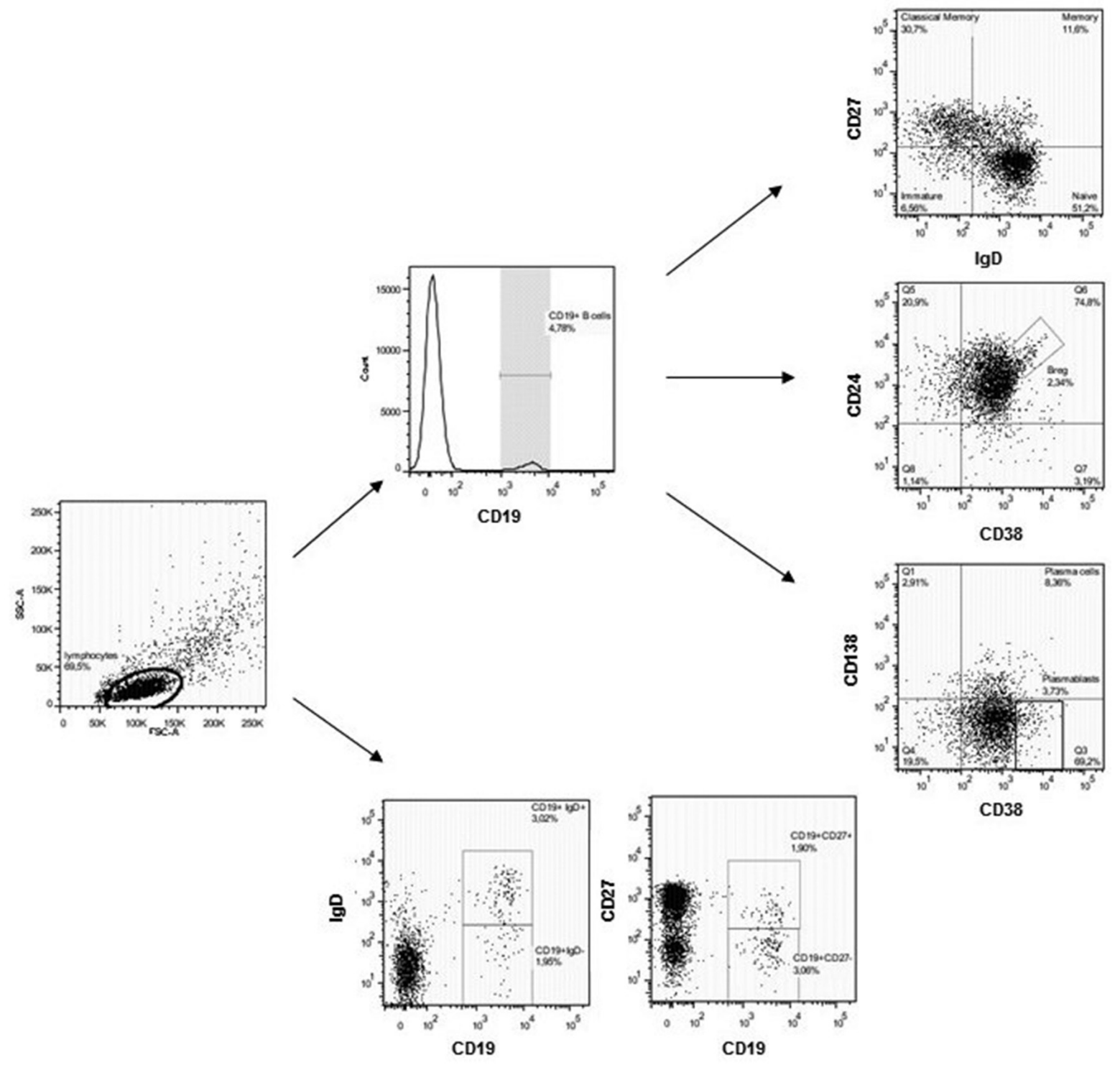

Figure 1. Flow cytometric analysis of B cells subtypes in peripheral blood. CD19+ B cells were selected in the lymphocyte gate, whereas remaining $\mathrm{B}$ cell subsets were selected in the CD19 gate. The CD19 gate was drawn based on CD19 positivity and side scatter characteristics. CD19+ B cells were distributed to six B cell subtypes according to surface expression of CD27, IgD, CD38, CD24, and CD138 
Table 2. Clinical and demographic features of patients with relapsing-remitting multiple sclerosis, secondary progressive multiple sclerosis, and the healthy controls during blood sampling

\begin{tabular}{|c|c|c|c|c|}
\hline & $\begin{array}{c}\text { RRMS } \\
(n=8)\end{array}$ & $\begin{array}{l}\text { SPMS } \\
(n=11)\end{array}$ & $\begin{array}{c}\text { HC } \\
(n=20)\end{array}$ & $\mathrm{p}$ \\
\hline Sex (female/male) & $6 / 2$ & $3 / 8$ & $12 / 8$ & $0.087^{*}$ \\
\hline Age (years) & $38.9 \pm 6.9$ & $42.4 \pm 8.3$ & $31.5 \pm 6.1$ & $0.112^{* *}$ \\
\hline $\begin{array}{l}\text { Age at disease onset } \\
\text { (years) }\end{array}$ & $24.6 \pm 6.0$ & $27.5 \pm 9.7$ & - & $0.148^{\dagger}$ \\
\hline $\begin{array}{l}\text { Disease duration } \\
\text { (years) }\end{array}$ & $14.3 \pm 3.5$ & $14.8 \pm 5.4$ & - & $0.485^{\dagger}$ \\
\hline Number of relapses & $6.2 \pm 4.9$ & $8.1 \pm 3.2$ & - & $0.048^{\dagger}$ \\
\hline $\begin{array}{l}\text { Number of patients } \\
\text { with CSF OCB }\end{array}$ & 4 & 8 & - & $0.376^{*}$ \\
\hline EDSS score & $2.7 \pm 0.9$ & $5.0 \pm 1.6$ & - & $0.006^{\text {t十 }}$ \\
\hline \multicolumn{5}{|c|}{$\begin{array}{l}\text { CSF: Cerebrospinal fluid, OCB: Oligoclonal bands, EDSS: Expanded Disability } \\
\text { Status Scale, RRMS: Relapsing-remitting multiple sclerosis, SPMS: Secondary } \\
\text { progressive multiple sclerosis, HC: Healthy controls. } \\
\text { Numerical values were signified in the form of average } \pm \text { standard deviation. } \\
{ }^{*} \text { Chi-square, }{ }^{* *} \text { ANOVA, tStudent's t-test, ttMann-Whitney U }\end{array}$} \\
\hline
\end{tabular}

Also, the distribution of $\mathrm{B}$ cell subsets among patients with RRMS, SPMS, and the HC was found to be comparable and statistically insignificant using ANOVA and Tukey's post-hoc test. Only higher naïve B cell frequency tendency was determined in patients with RRMS as compared with those with SPMS and the HC. However, this difference did not attain statistical significance $(p=0.128)$. Frequencies of immature $(p=0.529)$, classic memory $(\mathrm{p}=0.175)$, plasma $(\mathrm{p}=0.707)$, plasmablast $(\mathrm{p}=0.337)$, and Breg cells $(\mathrm{p}=0.312)$ were not different in the RRMS, SPMS or HC groups (Figure 3).

\section{Discussion}

Our study failed to find a significant change in a broad spectrum of B cell subpopulation types of patients with RRMS and SPMS, thus arguing against a crucial role for B cells in the progression of MS. Elevated CSF levels of brain antigenspecific activated B cells and memory B cells (both of which are indicators of germinal center-based antigen presentation) have been observed in CIS and in earlier stages of RRMS. Moreover, CSF counts of these antigen-specific B cells have been associated with higher rates of MRI lesions, attack numbers, and increased chances of conversion from CIS to RRMS (10).

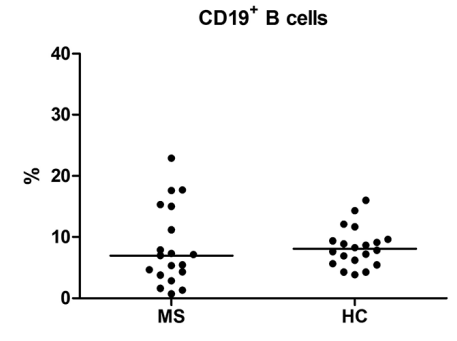

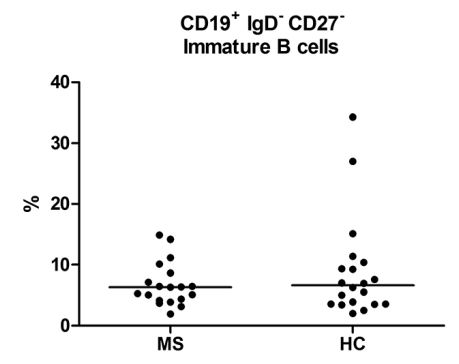

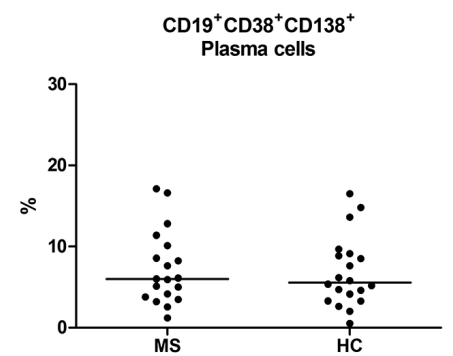

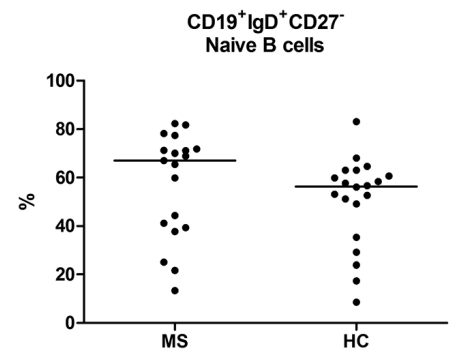
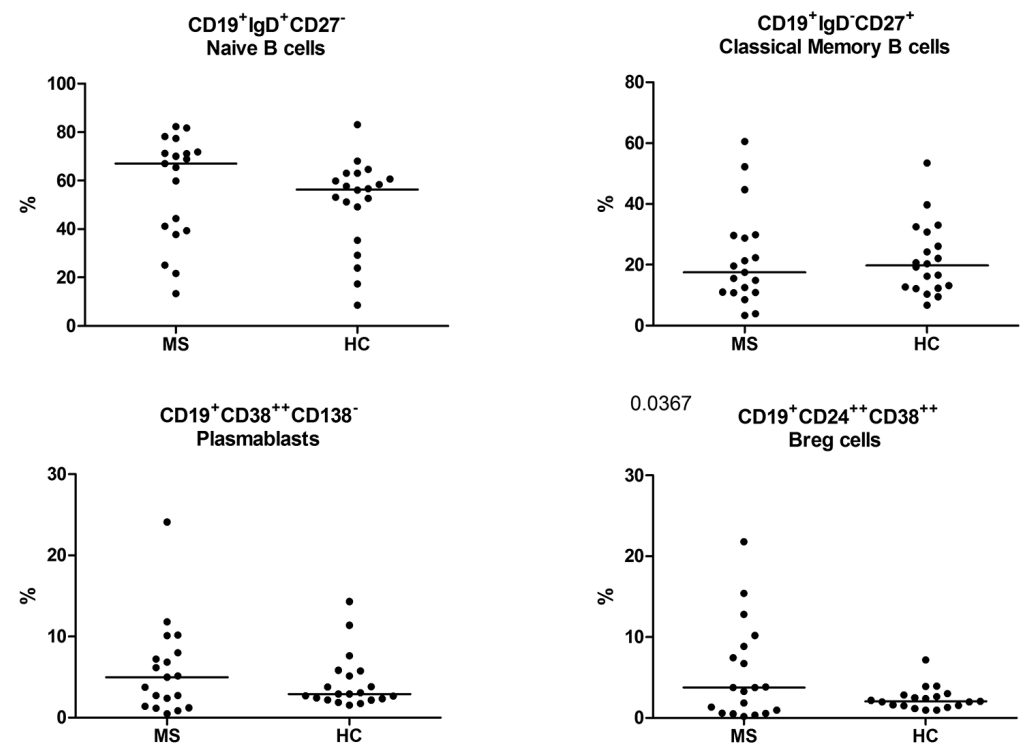

Figure 2. Peripheral blood B cell subsets in patients with multiple sclerosis and healthy controls. Scatter-plots represent percentages of B cell-subsets. Horizontal lines indicate median values. MS: Multiple sclerosis, HC: Healthy controls 
$\mathrm{B}$ cells have been shown to emerge in the CSF of patients even before OCB and MRI lesion formation in MS (10), suggesting that antigen-specific B cells are actively involved in MS attacks. A possible explanation for these findings is that increased $\mathrm{T}$ helper-mediated presentation of brain antigens to germinal center-located B cells elevates the number of pathogenic B cells that cross the blood-brain barrier and inflict damage upon the myelin sheath in the periventricular region, thus inducing new MS attacks and MRI lesions. This above-mentioned process and other potential B cell-mediated disease mechanisms do not seem to be occurring during transition to the progressive stage of MS, because no significant change was observed in peripheral blood memory B cell, plasmablast, and plasma cell numbers of patients with RRMS and SPMS. This finding supports the notion that non-inflammatory mechanisms play a leading role in the transition to SPMS, such as increased oxidative stress, neuroaxonal damage, and mitochondrial dysfunction (11). Naturally, our study does not rule out the possibility of potential B cell subset changes that might occur in the intrathecal compartment of patients with MS during the progressive stage.

Regulatory B cells are known to be suppressed during the clinical course of autoimmune disorders $(12,13,14)$. However, no significant alterations were observed in regulatory B cell frequencies of the patients with RRMS and SPMS, suggesting that conversion from the relapsing to progressive form of disease is not generated by deficiency or suppression of regulatory $\mathrm{B}$ cells. The regulatory $\mathrm{B}$ cell phenotype that we used in our experiment is the most classic and universally accepted B cell subpopulation. Nevertheless, there are other less well identified regulatory B cell types (15). These B cell subsets also need to be investigated in patients with RRMS and SPMS before drawing a final conclusion on the role of $\mathrm{B}$ regulation in MS.

\section{Study Limitations}

As a limitation of our study, all patients with MS included in the study were under immunomodulating drug treatment and thus some of our measurements might have been influenced by these treatments. Most of our patients were under interferonbeta and glatiramer acetate treatment and these reagents have been reported not to influence B cell subset frequencies in peripheral blood (16). Nevertheless, we would recommend repeating $B$ cell subset measurements in treatment-naïve patients with RRMS and SPMS to have a more clear assessment of $\mathrm{B}$ cells in MS.
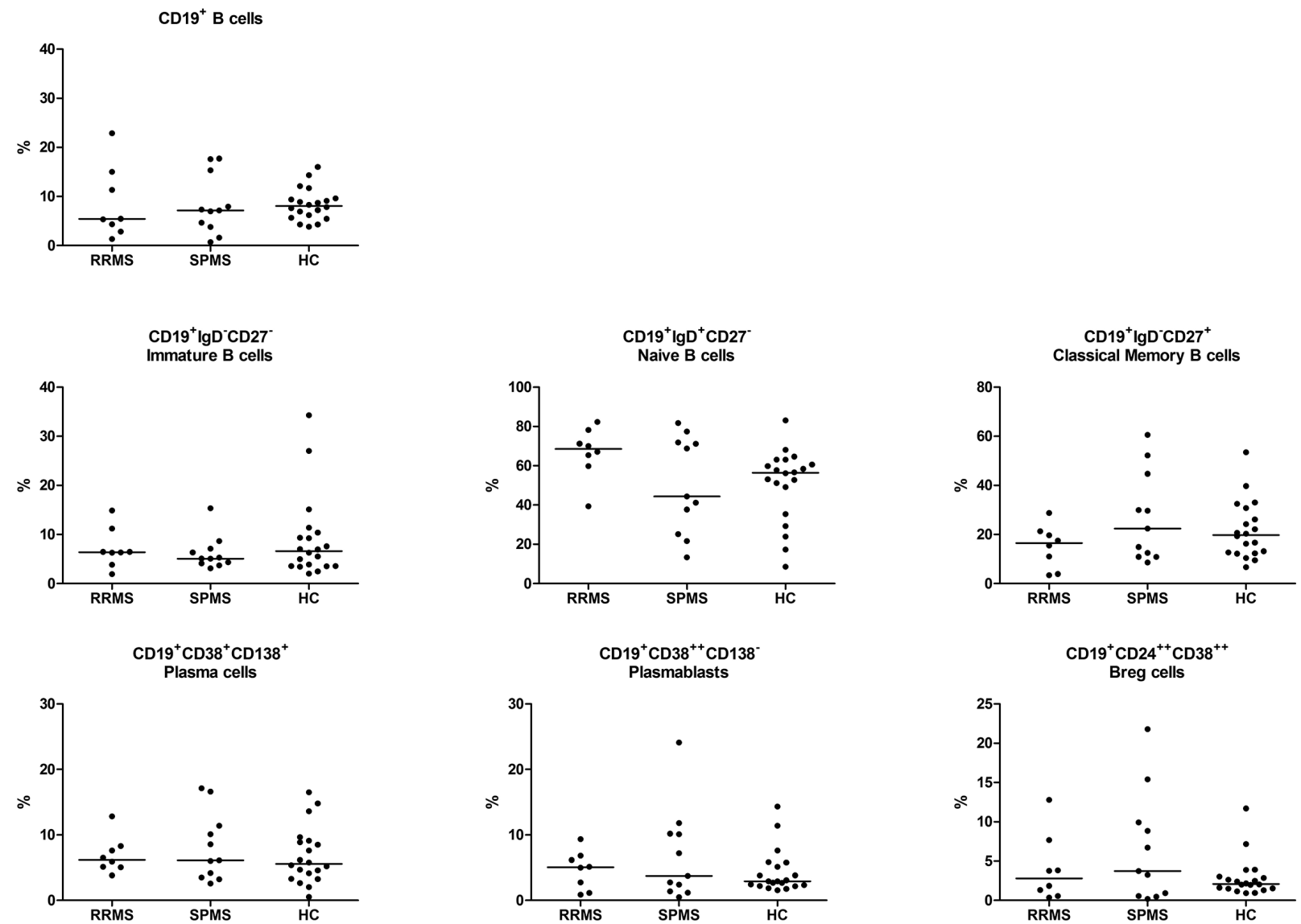

Figure 3. Peripheral blood B cell subsets in patients with relapsing-remitting multiple sclerosis and secondary progressive multiple sclerosis. Scatterplots represent percentages of B cell-subsets. Horizontal lines indicate median values.

RRMS: Relapsing-remitting multiple sclerosis, SPMS: Secondary progressive multiple sclerosis, HC: Healthy controls 


\section{Conclusion}

A major finding of our study was that there were no distinguishing features between patients with RRMS and SPMS by means of peripheral blood memory B cell subset frequencies. Although B cells are known to accumulate in the cortical and meningeal regions of the CNS to establish tertiary lymphoid organs and potentially contribute to disease progression in a sizeable portion of patients with progressive MS, our results suggest that major B cell alterations occur during earlier stages of MS in peripheral blood, but not during the progression of the disease. Thus, peripheral blood B cell subset measurements are not likely to be used as a biomarker for the prediction of disease progression.

\section{Ethics}

Ethics Committee Approval: The study were approved by the Haydarpasa Numune Training and Research Hospital's Local Ethics Committee (Protocol number: HNEAH-KAEK 2016/110).

Informed Consent: All subjects gave informed consent.

Peer-review: Externally and internally peer-reviewed.

\section{Authorship Contributions}

Surgical and Medical Practices: V.Y., R.T., Concept: V.Y., R.T., Design: V.Y., R.T., Data Collection or Processing: V.Y., D.A.T., C.U., D.Ö.Y., S.A.Ç., Analysis or Interpretation: V.Y., R.T., Literature Search: V.Y., Writing: V.Y.

Conflict of Interest: No conflict of interest was declared by the authors.

Financial Disclosure: The authors declared that this study received no financial support.

\section{References}

1. Claes N, Fraussen J, Stinissen P, Hupperts R, Somers V. B Cells Are Multifunctional Players in Multiple Sclerosis Pathogenesis: Insights from Therapeutic Interventions. Front Immunol 2015;6:642.

2. Prineas JW, Multiple sclerosis: presence of lymphatic capillaries and lymphoid tissue in the brain and spinal cord. Science 1979;203:1123-1125.

3. Magliozzi R, Howell O, Vora A, Serafini B, Nicholas R, Puopolo M, Reynolds R, Aloisi F. Meningeal B-cell follicles in secondary progressive multiple sclerosis associate with early onset of disease and severe cortical pathology. Brain 2007;130:1089-1104.
4. Wekerle H. B cells in multiple sclerosis. Autoimmunity 2017;50:57-60.

5. de Andrés C, Tejera-Alhambra M, Alonso B, Valor L, Teijeiro R, RamosMedina R, Mateos D, Faure F, Sánchez-Ramón S. New regulatory CD19(+) $\mathrm{CD} 25(+) \mathrm{B}$-cell subset in clinically isolated syndrome and multiple sclerosis relapse. Changes after glucocorticoids. J Neuroimmunol 2014;270:37-44.

6. Kuerten S, Pommerschein G, Barth SK, Hohmann C, Milles B, Sammer FW, Duffy CE, Wunsch M, Rovituso DM, Schroeter M, Addicks K, Kaiser CC, Lehmann PV. Identification of a B cell-dependent subpopulation of multiple sclerosis by measurements of brain-reactive B cells in the blood. Clin Immunol 2014;152:20-24.

7. Haas J, Bekeredjian-Ding I, Milkova M, Balint B, Schwarz A, Korporal M, Jarius S, Fritz B, Lorenz HM, Wildemann B. B cells undergo unique compartmentalized redistribution in multiple sclerosis. J Autoimmun 2011;37:289-299.

8. Lee-Chang C, Zéphir H, Top I, Dubucquoi S, Trauet J, Prin L, Vermersch P. B-cell subsets up-regulate $\alpha 4$ integrin and accumulate in the cerebrospinal fluid in clinically isolated syndrome suggestive of multiple sclerosis onset. Neurosci Lett 2011;487:273-277.

9. Kuenz B, Lutterotti A, Ehling R, Gneiss C, Haemmerle M, Rainer C, Deisenhammer F, Schocke M, Berger T, Reindl M. Cerebrospinal fluid B cells correlate with early brain inflammation in multiple sclerosis. PLoS One 2008;3:e2559.

10. Qin Y, Duquette P, Zhang Y, Olek M, Da RR, Richardson J, Antel JP, Talbot P, Cashman NR, Tourtellotte WW, Wekerle H, Van Den Noort S. Intrathecal B-cell clonal expansion, an early sign of humoral immunity, in the cerebrospinal fluid of patients with clinically isolated syndrome suggestive of multiple sclerosis. Lab Invest 2003;83:1081-1088.

11. Mahad DH, Trapp BD, Lassmann H. Pathological mechanisms in progressive multiple sclerosis. Lancet Neurol 2015;14:183-193.

12. Heinemann K, Wilde B, Hoerning A, Tebbe B, Kribben A, Witzke O, Dolff S. Decreased IL-10(+) regulatory B cells (Bregs) in lupus nephritis patients. Scand J Rheumatol 2016;45:312-316.

13. Li W, Tian X, Lu X, Peng Q, Shu X, Yang H, Li Y, Wang Y, Zhang X, Liu Q, Wang G. Significant decrease in peripheral regulatory B cells is an immunopathogenic feature of dermatomyositis. Sci Rep 2016;6:27479.

14. Guptill JT, Yi JS, Sanders DB, Guidon AC, Juel VC, Massey JM, Howard JF Jr, Scuderi F, Bartoccioni E, Evoli A, Weinhold KJ. Characterization of B cells in muscle-specific kinase antibody myasthenia gravis. Neurol Neuroimmunol Neuroinflamm 2015;2.e77.

15. Rosser EC, Blair PA, Mauri C. Cellular targets of regulatory B cell-mediated suppression. Mol Immunol 2014;62:296-304.

16. Habib J, Deng J, Lava N, Tyor W, Galipeau J. Blood B cell and regulatory subset content in multiple sclerosis patients. J Mult Scler (Foster City) 2015;2:1000139. 